\title{
Margaritifera auricularia (Unionoidea, Margaritiferidae), the giant freshwater pearl mussel rediscovered in Spain
}

\author{
R. Araujo (*) and M. A. Ramos (*)
}

Margaritifera auricularia was described by Spengler in 1793. Since then specimens have been found in several localities in Western Europe and North Africa, often as fossils. However no living specimens have been scientifically recorded since 1917 (Haas, 1917). This author was the only one to study live specimens, collected in the Ebro River in Spain, publishing a short paper about its anatomy (Haas, 1924). As no more specimens were ever found, no data exist about its reproductive habits, spawning season nor is there a description of its larval stages.

In a recent survey of Spanish Rivers to inventory the Habitats Directive (Directive 92/43/CEE) non-insect invertebrate species (Ramos, 1998), we found living populations of this giant pearl mussel in a very ancient channel (Imperial Canal) of the Ebro River (Araujo \& Ramos, 1996) and in the Ebro (Álvarez Halcón, 1998), both in Aragón. More recently, there has been news about other $M$. auricularia populations living in the lower course of the Ebro river and in one of its irrigation channels (Altaba, 1997), both in Catalonia.

An interesting theory exists about the specificity between M. auricularia and the Western European sturgeon Accipenser sturio (Linnaeus, 1758), a relict fish in European rivers and extinct in Spain. Both species occur together in Pleistocene deposits (Preece, 1988) and both have been declining since the first half of this century. With this theory in mind, we introduced several sturgeons into an aquarium with mussels, realizing that all mussels began to spawn. In the aquarium the mussels released all their larval stages, from unfertilized eggs to mature glochidia, passing through all intermediate stages.
The glochidium of $M$. auricularia is very small (about 140 microns) and presents very small teeth. It is of the hookless type, as in other known species of the genus (Araujo \& Ramos, 1998). This kind of glochidium specifically attaches itself to the gill filaments of the fish, whereas the hooked ones, typical of other genera, also attach themselves to the fins.

Inmediately after the glochidia were released, we observed how they attached to the fish gills. We excised the gill filaments of the sturgeons 1, 2, 3, 4, 5 hours and 2, 3, 5, 13, 34 and 60 days after the begining of glochidia release. Now we are studying histological and scanning samples of these gill filaments in order to investigate the encystment process and to discover the period the glochidia need to complet their metamorphosis.

Timing and length of the glochidial release period in the wild has been determined by collecting drift samples. With these data, fish were collected by electrofishing in order to investigate their susceptibility to the glochidia.

The large size of all the specimens from the Imperial Canal population and the longevity achieved by species of this genus (around 100 years) suggest that this population may not have reproduced for many years. This leads us to ask wether the species has lost its reproductive capability, if it is unable to complete larval maturation or do the juveniles simply have a different habitat that we have not been able to find up to now?

In situ observations suggest that the species should be more common, as occurs with other related genera (i. e. Unio, Psilunio, Anodonta) in the study area, if any kind of fish were compatible with

* Museo Nacional de Ciencias Naturales (C.S.I.C.). C/ José Gutiérrez Abascal 2. 28006 Madrid. Spain.

E-mail: rafael@mncn.csic.es (R. Araujo); m.ramos@mncn.csic.es (M. A. Ramos) 
its larval requirements. Evaluation of the possibility that other fish species may be parasitized by glochidia of M. auricularia, and of the success of this unusual cycle in captivity and in the wild is yet to come. In addition, the results of a molecular study currently in progress, can provide information on the genetic variability of this population and possible reproductive strategies. This kind of results are of interest for subsequent application of species recovery plans and reintroduction policies.

Fortunately, after our rediscovery of Margaritifera auricularia and the corresponding report to the Dirección General de Conservación de la Naturaleza, the Comisión Nacional de Protección de la Naturaleza has included the species in the National Endangered Species List (Royal Decree 439/90) in the category of "threatened with exinction", then being protected by the Law 4/1989. Margaritifera auricularia was the first invertebrate species on this List.

\section{ACKNOWLEDGEMENTS}

The study carried up to now received finantial support from the ICONA-CSIC Project "Inventory of Invertebrate species listed in Appendix II of Council Directive 92/43/EEC" and "Fauna Ibérica" Project (DGES PB96-0235). Thanks also to the Department of Agriculture and the Environment of the Diputación General de Aragón (Aragón Regional Government) and to the Confederación Hidrográfica del Ebro (CHE) for permission to collect the animals. S. Jiménez, D. Bragado and C. Grande made an invaluable contribution in the laboratory. L. Ashcroft corrected the English.

\section{References}

AltabA, C. R., 1997. Al límit de l'éxtinció: Margaritifera auricularia (Bivalvia: Unionoida). Butlleti de la Institució Catalana d'Historia Natural, 65: 137-148.

Álvarez Halcón, R.M. 1998. Salvar la almeja de rio: Margaritifera auricularia, una especie en peligro de extinción. Trébede, Mensual Aragonés de Análisis, Opinión y Cultura, 21: 7-14.
Araujo, R. \& Ramos, M. A. 1996. The last living population of Margaritifera auricularia (Spengler, 1783). Abstracts of Molluscan Conservation. A strategy for the 21st Century. National Museum \& Gallery, Cardiff (Gales, Inglaterra) Seddon, M.B. \& Killeen, I. (eds.): 1-2.

Araujo, R. \& Ramos, M. A., 1998. Description of the glochidium of Margaritifera auricularia (Spengler, 1793) (Bivalvia, Unionidae). Philosophical Transactions of the Royal Society of London B, 353: 15531559.

HAAS, F., 1917. Estudios sobre las Náyades del Ebro. Boletín de la Sociedad Aragonesa de Ciencias Naturales, XVI: 71-82.

HAAS, F., 1924. Anatomische Untersuchungen an europäischen Najaden. I. Archiv für Molluskenkunde, 56: 66-82.

Preece, R. C. 1988. A second British interglaciar record of Margaritifera auricularia. Journal of Conchology, 33(1): 50-51.

RAmos, M.A., 1998. Implementing the Habitats Directive for molluscs species in Spain. Journal of Conchology, Special Publication, 2: 125-132. 